\title{
Correction to: Trichuris trichiura isolated from Macaca sylvanus: morphological, biometrical, and molecular study
}

Julia Rivero, Ángela María García-Sánchez, Antonio Zurita, Cristina Cutillas and Rocío Callejón

Correction to: BMC Vet Res 16, 445 (2020)

https://doi.org/10.1186/s12917-020-02661-4

The original article [1] contains an incorrect Funding statement which the author would like to change to the following:

\section{Funding}

This work was financially supported by FEDER/Ministry of Science and Innovation - State Research Agency (CGL2017-83057). The Junta de Andalucía (BIO-338), and a grant from the V and VI Plan Propio de Investigacion of the University of Seville, Spain

Published online: 14 April 2021

\section{Reference}

1. Rivero J, García-Sánchez ÁM, Zurita A, Cutillas C, Callejón R. Trichuris trichiura isolated from Macaca sylvanus: morphological, biometrical, and molecular study. BMC Vet Res. 2020;16(1):445. https://doi.org/10.1186/s12917-020-02 661-4.

*Correspondence: cutillas@us.es

Department of Microbiology and Parasitology, Faculty of Pharmacy,

University of Seville, Professor García González 2, 41012 Seville, Spain

(C) The Author(s). 2021 Open Access This article is licensed under a Creative Commons Attribution 4.0 International License, which permits use, sharing, adaptation, distribution and reproduction in any medium or format, as long as you give appropriate credit to the original author(s) and the source, provide a link to the Creative Commons licence, and indicate if changes were made. The images or other third party material in this article are included in the article's Creative Commons licence, unless indicated otherwise in a credit line to the material. If material is not included in the article's Creative Commons licence and your intended use is not permitted by statutory regulation or exceeds the permitted use, you will need to obtain permission directly from the copyright holder. To view a copy of this licence, visit http://creativecommons.org/licenses/by/4.0/ The Creative Commons Public Domain Dedication waiver (http://creativecommons.org/publicdomain/zero/1.0/) applies to the data made available in this article, unless otherwise stated in a credit line to the data. 